\title{
The Medieval Bishop's Palace in Milicz. 3D Reconstruction as a Method of a Research Hypotheses Presentation
}

\author{
JUSTYNA KOLENDA, MAEGORZATA MARKIEWICZ \\ Polish Academy of Science, Poland
}

As a result of the intensive development of multimedia, 3D visualizations of various kinds of historically, artistically or scientifically valuable objects became standard at the beginning of the 21 st century. What triggered the construction of three-dimensional visualizations was the will to protect cultural heritage especially historical monuments which are in ruins and exposed to further destruction - as well as the need to disseminate information about such objects beyond a small group of specialists. Another catalyst for this was the need to verify the existing proposals for reconstructions or research hypotheses. The bishop's palace in Milicz (Poland) was probably built in the late thirteenth or early fourteenth century. It was a brick building whose layout was typical of ducal buildings known in Silesia. The erection of the building in Milicz was connected with the creation of the Church castellany in this area. The visualization of the oldest phase of the bishop's palace in Milicz is part of the project Regni custodiam et clavem - Santok and clavis regni Poloniae - Milicz as an example of two border towns, implemented by the Institute of Archaeology and Ethnology of the Polish Academy of Sciences and financed with the funds of the National Program for the Development of Humanities for the years 2011-2017 (number 11H 110184 80). Virtual reconstructions were based on the analysis and interpretation of source materials, in accordance with the guidelines contained in the London Charter. The purpose of the visualization is to present the history of the building to the residents of Milicz and tourists and, in the long run, to allow local authorities to take steps towards the preservation and revitalization of the bishop's palace.

Key words:

3D visualization, reconstruction, the bishop's palace in Milicz, the London Charter.

SDH Reference:

Justyna Kolenda and Małgorzata Markiewicz. 2017. The Medieval Bishop's Palace in Milicz. 3D

Reconstruction as a Method of a Research Hypotheses Presentation. SDH, 1, 2, 428-443.

DOI : $10.14434 /$ sdh.v1i2.23458

\section{INTRODUCTION}

Over the last few years there has been a very intensive development of digital media, such as computer visualization techniques, which have significantly extended research possibilities in the

Authors' address: Justyna Kolenda And Małgorzata Markiewicz, Institute of Archaeology and Ethnology Polish Academy of Sciences Centre for Late Antique and Early Medieval Studies, ul. Więzienna 6, 50-118 Wrocław, Poland; email: jko@arch.pan.wroc.pl; mma@arch.pan.wroc.pl

Permission to make digital or hardcopies of part or all of this work is granted without fee according to the open access policy of SDH.

(C) 2017 SDH Open Access Journal

Studies in Digital Heritage, Vol. 1, No. 2, Publication date: December 2017 
field of humanities, including the disciplines researching the past [Sylaiou and Patias 2004; Hermon and Kalisperis 2011]. Digital technologies provide contemporary researchers with a set of tools and methods enabling them, apart from verifying the existing research hypotheses and putting forward new ones, to create knowledge about the past by the development and presentation of spatial images of historic architecture [Johnson 2007; Riedel and Bauer 2008]. One of the consequences of the use of these new media is the great popularity of three-dimensional visualizations of the buildings of historic value which are part of local cultural heritage.

\section{RESEARCH OBJECTIVES}

We present in this article the method and tools that were applied to develop a 3D visualization of the medieval palace in Milicz (Poland). This is a multi-stage historic object which was extended and modernized many times over its seven-hundred-year-long history (Fig. 1).
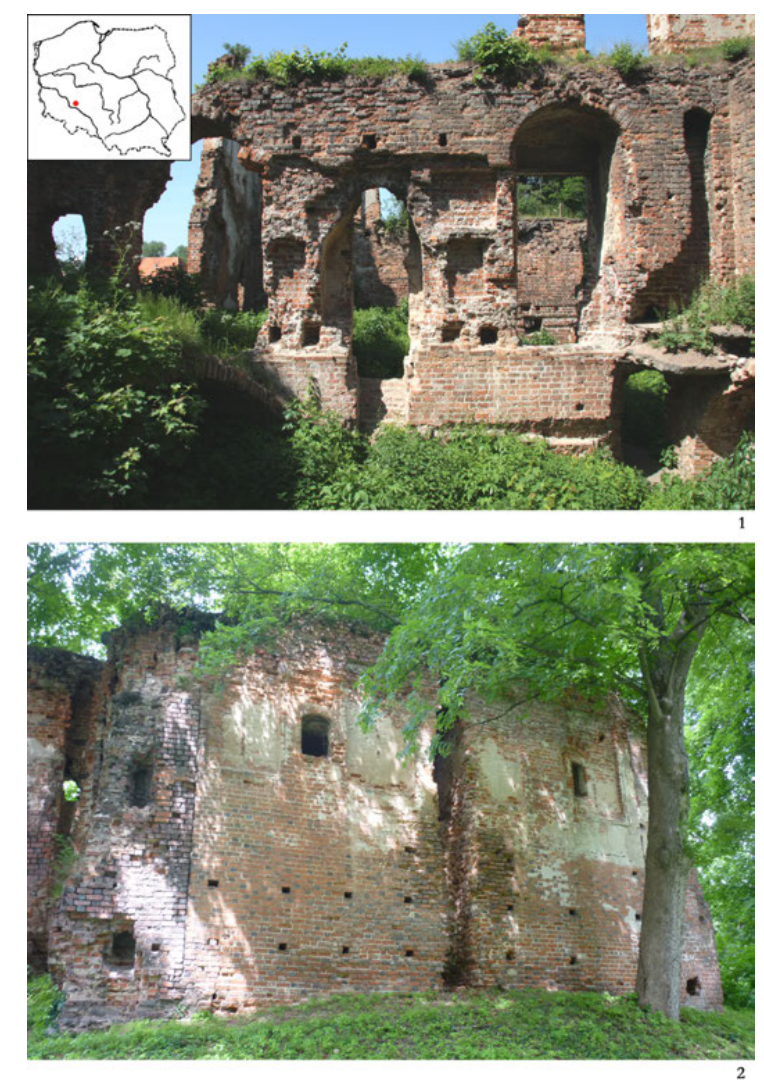

Figure 1. The bishop's palace in Milicz: above - west side; below - south side (photo by M. Markiewicz).

The palace was originally constructed at the end of the 13th century or the beginning of the 14th century and presumably it was connected with the investment made by the bishop of Wrocław. In 1358, it was sold to Duke Kondrat I of Oleśnica, who remodeled it. From 1494 it was the seat of the 
Kurzbach family and at the end of the 18th of the Maltzan family, who later moved to a newly built residence [Chorowska and Kudła 2005]. The building began to serve a secondary role and this is when the process of its slow deterioration started, which significantly intensified in 1945 because of WWII.

The decision to develop a visualization of the oldest stage of the palace resulted from the fact that numerous and often inconsistent proposals for the reconstruction of the specific chronological stages of this building were in the literature on the subject. J. Gottschalk, for instance, noted that the masonry castle was built by the Dukes of Oleśnica after the invasion of the Hussites in 1432 [Gottschalk 1939, 43], whereas B. Guerquin indicated that the middle of the 14th century was the time when the castle was constructed on an irregular plan, with residential buildings located in the southern part of the yard and an enclosure wall with the entrance from the eastern side. The building with a great hall was supposedly constructed after the fire in 1536. [Guerquin 1957, 59]. Less than twenty years later, the same researcher reconstructed the oldest design featuring the residential tower on a rectangular plan with two outside buttresses from the southern side and with three open space floors [Guerquin 1974, 198]. The proposal by J. Pilch is also in line with the layout described above. In his opinion, a castle was supposedly built in this place according to an irregular plan surrounded by a wall with an entrance on the eastern side and a residential building in its southern part. Just like his predecessors, he also claims that after the fire in 1536 a new building was constructed there with a great hall whose ceiling was supported by a single pillar [Pilch 1978, 167]. The spatial layout, the size, and the chronology suggested by the researchers mentioned above were verified during the archeological and architectural research conducted in the 1980s [Rozpędowski and Kudła 1987; Kudła 1988]. The findings of this research were discussed in two articles by M. Chorowska and A. Kudła [2005] as well as M. Chorowska [2008]. According to those researchers, the object was built much earlier, in the 13th century or at the beginning of the 14th century, as a long free-standing house that functioned as a palace of the bishop of Wrocław [Chorowska, Kudła 2005, 86-87]. This short outline of the history of that palace is confirmed by numerous remodelings, which each time changed its layout, size, and form in compliance with the architectural program which was popular in each period, while at the same time eliminating older elements. The stages mentioned above refer to remodeling as well as the disappearance of the older elements of architecture. Unfortunately, during the development of the visualization it was quite difficult to identify the oldest elements, which survived only partially. The objectives of the three-dimensional visualization were:

- $\quad$ to present the oldest stage - the bishop's palace (currently completely invisible in the ruins and inaccessible to the potential viewers) - one of this type of structure built in the Middle Ages in Europe [Chorowska 2008];

- to present the reconstruction of this building according to the plan that is popular in the literature on this subject and to begin an academic discussion of its correctness;

- to present to the viewers the value of the object, to provide information about it by popularizing its three-dimensional reconstruction. 


\section{PROCEDURE}

The issues connected with the 3D visualization of architecture have many aspects which should be considered at several research levels. These include: the choice of a historic site and the evaluation of the feasibility of the development of a spatial image based on it, its documentation method (traditional methods, photogrammetry, scanning), and also the selection of tools and assumed principles of building databases, which often provide the basis for the evaluation of the reliability of the whole process of visualization development. The final effect of this sort of project, namely the spatial model, is usually one of many possible proposals for the visual presentation of the past affecting the imagination of modern society. In each case, the right procedure should be selected, which must be suitable for the conditions of the original elements of the object and the expectations of the contemporary viewers. This problem is especially evident when you compare the methods applied when developing 3D models of objects with poorly preserved original fragments, such as the ruins in Milicz, to those applied in the visualizations of well-preserved structures. In the first case, the use of older architectural documentation developed with the use of traditional methods determines the correctness and consequently the reliability of the visualization. It includes information that has been irretrievably lost over the last 60 years as a result of continuous deterioration. This situation requires the assumption of specific procedures and tools to combine qualitatively varied sources: the older, often graphic and descriptive documentation, with the newer, digital data collected for still existing parts of the objects. Obviously, this procedure is different from that used when developing visualizations of well-preserved structures for which digital data are available and which allow for new documentation as well as higher research quality. Thus, there is a clear discrepancy regarding the quality of sources between, on the one hand, the archival documentation developed with traditional methods whose processing requires the use of adequate procedures and, on the other hand, the documentation developed nowadays with the use of the latest research methods (e.g. laser scanning). It should be kept in mind that any visualization of seriously damaged historic structures is only one kind of proposal for the reconstruction of such an object, developed on the basis of its original fragments and known analogies, as well as the experience and knowledge of the persons involved in the development of a spatial image.

The use of 3D visualization to reconstruct the historic structure in Milicz had several purposes, the most important of which was the possibility of better rendering and consequently better understanding of the form and function of the palace. The computer-generated virtual space provides at present an important research environment for experiments. It is possible to create and analyze alternative model designs that provide the basis for the research process. Through the application of this method of reconstruction of a historic site, it is possible to generate any number of images of the palace and individual rooms (general views, details, close-ups, any layout images or scale). It is also possible to use this method to reconstruct the poorly preserved elements of architecture in several variants and critically analyze the spatial images developed in this way. Another benefit in favor of the use of 3D visualization in the process of reconstruction of the palace in Milicz was the great popularity and the high degree of acceptability of the images generated in the form of computer graphics by non-academic audiences. Posting them on Internet portals contributes to the broadening of the knowledge of the past with no need for those interested to visit the actual site. Citizens who are not history lovers or do not care about the past in general but do like computer

Studies in Digital Heritage, Vol. 1, No. 2, Publication date: December 2017 
graphics also find them interesting. Furthermore, this type of reconstruction also affects people who are fascinated by new technological developments, including the developers of computer games. It can then be claimed that the use of this method of reconstruction of the bishop's palace increases the possibilities for research on this very historic object and the 3D model promotes interest from contemporary society.

\section{THE RECONSTRUCTIVE PROCESS}

The different dating, form, and function of the oldest stage of the structure identified with the bishop's palace presented by M. Chorowska and A. Kudła prompted the work on its visualization. As mentioned above, the palace was remodeled a number of times, which is why the oldest elements of the building are often invisible under the walls from later stages.

The research work began with the question: Which parts of the presently existing main body of the building and which elements of the furnishings can be considered to be the remains of the oldest stage of the structure? The question forced the researchers to chronologically divide the original walls, assume specific research procedures, and apply an adequate conceptual framework. The problem was well presented in the article titled Visualizing Knowledge about Virtual Reconstructions of Ancient Architecture, whose authors stated the following in its introduction: "Photorealistic images tend to leave their viewers with the impression that the objects depicted actually exist. In the case that the viewer knows that the objects do not really exist - either because they have not yet been built or because they were destroyed - a photorealistic image nonetheless suggests that detailed information has been amassed about the objects being shown" [Strothotte et al. 1999]. The issue was then discussed in the London Charter, whose main objective is to draw the attention of the groups of specialists who apply computer graphics when developing spatial images of cultural heritage to the necessity of developing and applying reliable methods that would guarantee the historical accuracy of 3D models of historical sites. The virtual reconstruction of the bishop's palace in Milicz was developed as a result of analysis and interpretation of source materials in compliance with the guidelines of the London Charter, drafted in 2009 by the international team of researchers from the Department of Digital Humanities of King's College, London, and the Science and Technology in Archaeology Research Centre of the Cyprus Institute. That document presents the methods which guarantee the highest quality of 3D reconstructions and control mechanisms confirming the historical reliability of 3D models [Beacham et al. 2008; Bentkowska-Kafel 2008; Denard 2012].

\section{STAGES OF DEVELOPMENT}

\subsection{Survey of sources and data archiving}

The answer to the question asked above regarding the original remains of the oldest stage of the structure depended on a survey of the sources. This survey included the architectural documentation made in the 1960s when the condition of the building was much better and some parts of the basement were still accessible, the findings of archeological and architectural studies conducted in 
the 1980s, which determined the depth of the foundation, the structure of embankments and the presence of cobblestones in the yard. ${ }^{1}$

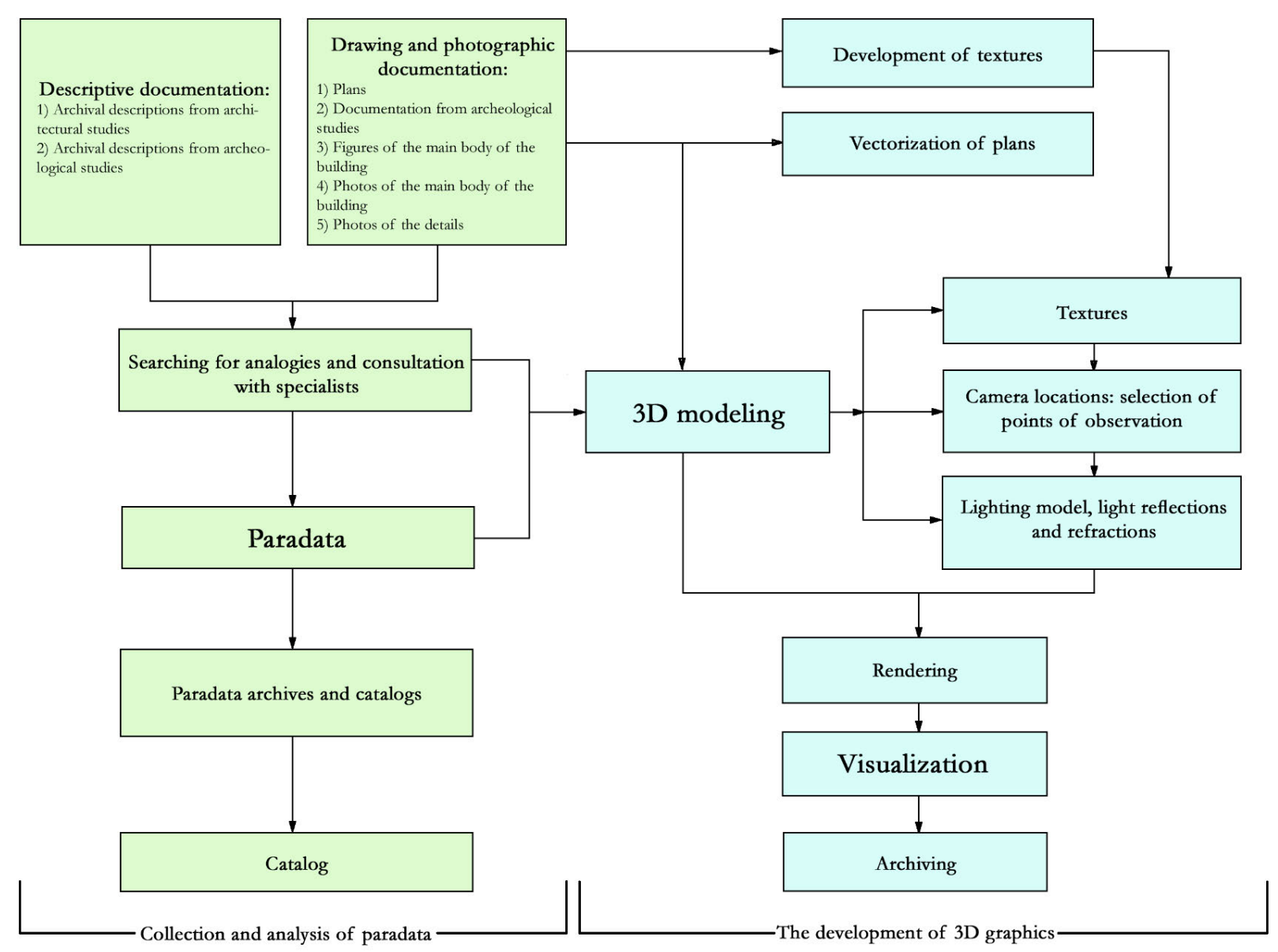

Figure 2. Process of reconstruction of the bishop's palace in Milicz (by M. Markiewicz).

The available images from the Early Modern Period were analyzed and they provided the basis for determining the extent of the palace remodeling and consequently the degree of intervention into the oldest stage. The survey also covered the written documents indicating the successive changes of ownership, which each time resulted in a remodeling or extension of the object in line with the architectural style popular at specific historical periods. These data were complemented with additional measurements and the photographic documentation made for the purposes of the model. At that stage, it was also important to consult specialists and to search for iconographic analogies available in the

\footnotetext{
${ }^{1}$ The studies were conducted by the Institute of History of Architecture, Art and Technology at Wrocław University of Technology in 1986-1988.
} 
subject literature and publications presenting various kinds of reconstructions of medieval structures, both in traditional and digital form. During that stage of the work, the available plans, drawings and photos of the main body of the palace, its rooms and architectural details, especially the parts of the object that do not exist anymore, were digitalized. The plans that were available during the reconstruction were traditional and digital to the scale 1:100. The documentation collected during the survey guaranteed the historical reliability indicated and strongly emphasized in the London Charter. The database which was developed included all collected information in catalogs (photos, drawings, descriptions). The paradata gathered in this way, i.e. the knowledge gained during the virtual reconstruction through analysis and interpretation of source material as well as through the analysis of missing data, has become the basis for further research on 3D reconstruction [Bentkowska-Kafel 2008, 44].

\subsection{Preparation of vector drawings and textures}

The reconstruction of the main body of the palace was based on the vector plan and the measurements conducted in the actual ruins. The documentation of the original external face of the walls above the foundation of the oldest stage and the face of the stone foundation was the basis for the textures, namely photos developed with the raster graphics software. The reconstruction was based on the original photos of the palace surfaces, i.e. the face of the first-floor stone wall as well as the brick bond at the second and third levels.

\subsection{Modeling and texturing}

This stage of the reconstruction work included modeling with the use of 3D graphics software Autodesk 3ds Max (Fig. 3). The process was divided into three stages. The first stage focused on the modeling of the landscape where the palace was built. The island with the moat around it, which does not exist anymore, was reconstructed. The next stage included the reconstruction of the palace, the cobblestone yard with a stone well, and an embankment with a gate. Some of these elements from around the palace were found during the archaeological studies conducted in the 20th century. The third stage was connected with the modeling of individual rooms, their furnishings, and architectural details.

The models were developed by transforming parametric (basic) and editable objects. The first ones were modified with the use of the parameters, which resulted in changing their geometry. That method provides a lot of flexibility. The editable objects do not provide such flexibility in the scope of parameter editing, but they can be edited by modifying sub-objects and using special editing features. The editable objects have a lot of editing features (modifiers) which are specific to individual types of objects. After the completion of the modeling process the previously developed textures were laid over specific elements of architecture. 

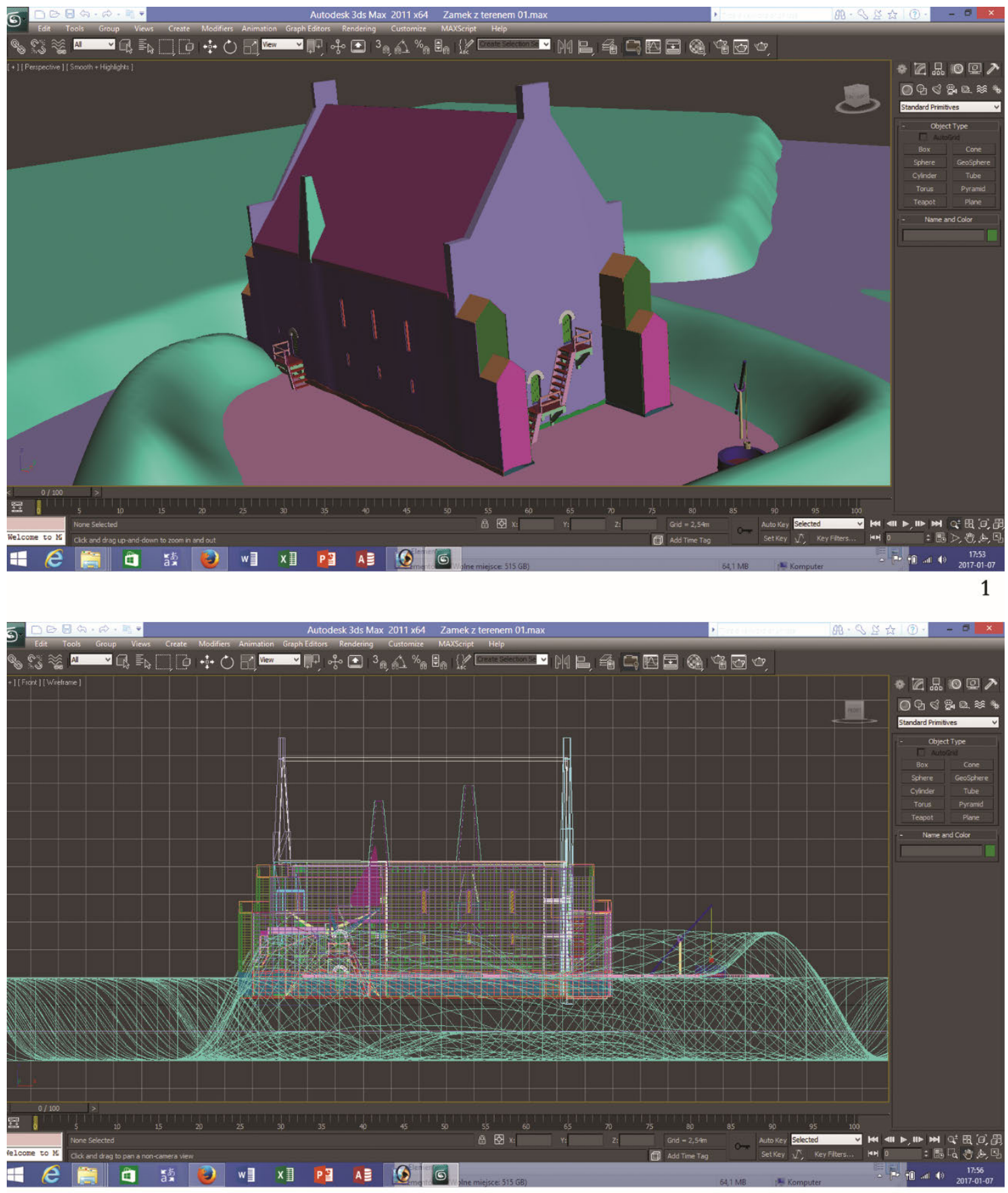

Figure 3. A three-dimensional model of the palace in Milicz: above - model 3D without textures; below - 3D model - orthogonal view (by M. Markiewicz). 


\subsection{Lighting and cameras}

After the textures were laid over individual 3D models, the virtual cameras were set. This way the socalled points of observation were selected, which affect the future perception of the whole visualization by the viewers. The adequate models of lighting, light reflection and refraction, corresponding to the lighting conditions outside and inside the building, were selected. The main body of the palace was illuminated with sunlight, whereas its individual rooms on the second and third floors were illuminated with sunlight streaming through the windows and illuminating the interiors. This way the lighting resembled that in the medieval interiors. The spaces in the basement had lights illuminating the rooms as well as spotlights, whose source was the candles placed in the corners of the rooms. This resulted in the effect of semi-darkness, typical of this type of room.

\subsection{Rendering and recording}

The last stage of the digital reconstruction of the palace was the rendering and recording of the completed digital images with the use of Autodesk 3ds Max, consisting of the analysis of the relationship between matter and light. The objective of the application of this procedure was to present the model as realistically as possible. V-Ray (Chaos Group) rendering engine was used to develop the visualization of the palace. This produced a more realistic image, as the lighting effects were rendered realistically.

It is often stressed in the literature on the subject that the photorealistic visualizations convey false impressions that the object presented really exists, or that the data used as a basis for the reconstruction provide a lot of reliability [Strothotte et al. 1999, 16-17]. That is why it is necessary to provide a description of the reconstruction process and show all hypothetical elements so that the viewers can interpret the image presented to them correctly. In order to avoid the problems with the loss of data, the individual stages of visualization were recorded according to the principles of the London Charter.

\section{RESULTS}

The critical analysis of the collected sources resulted in differentiating their reliability (Fig. 4). For this purpose the collected data were divided into three groups, including:

- original elements of the oldest stage of the structure of the highest informative value,

- elements confirming the presence of various types of facilities which were reconstructed on the basis of original traces (50\% probability of existence in the object),

- hypothetical elements whose presence was implied on the basis of general knowledge of such architectural structures which existed in the Middle Ages (10\% probability). The division which was applied is substantially justified by the guidelines of the London Charter [Bentkowska-Kafel 2008; Markiewicz 2014]. 

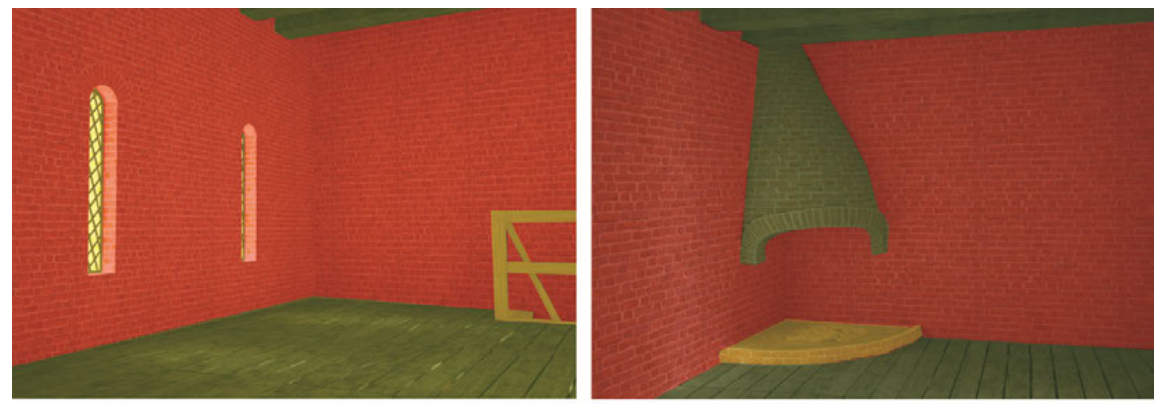

elements preserved ( $100 \%$ probability)



hypothetical elements ( $<10 \%$ probability)

Figure 4. The bishop's palace in Milicz. "A reliability meter" (by M. Markiewicz).
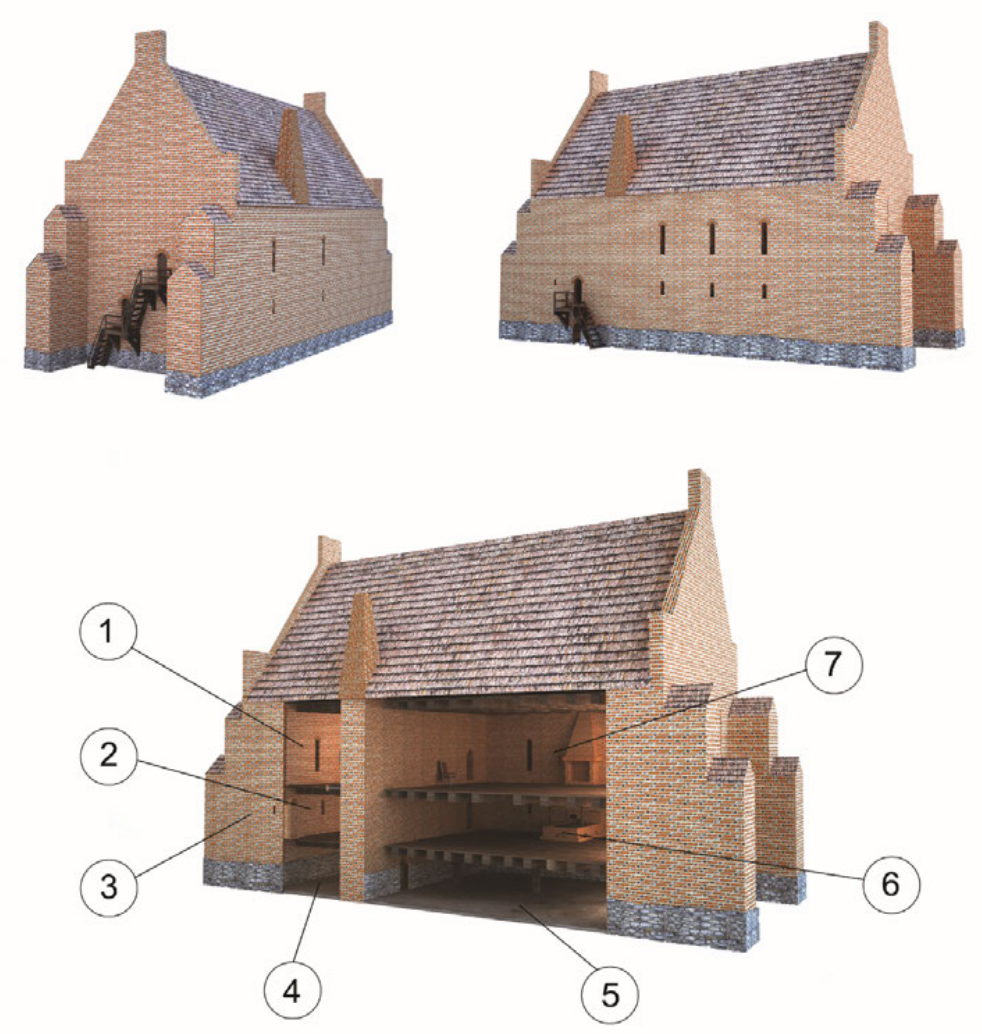

Figure 5. 3D visualization of the bishop's palace in Milicz: 1 - residential room; 2 - utility room; 3 - latrine; 4 basement; 5 - basement; 6 - kitchen; 7 - representative room (by M. Markiewicz). 
The original sources included the data regarding the size, form, and layout of the whole structure. It is assumed that the bishop's palace (Fig. 5) was constructed as a two-winged building with three floors on a rectangular plan with its longer axis oriented north-south (32-33x14 m). Its north and south parts (gable walls) had buttresses. The lowest level, the basement, was built of cobbles; the other two floors were built of brick in Flemish bond. The southern part of the building, which was used for residential and utility purposes, has original windows on the first floor, whereas its northern, representative part had a large, single room called the great hall $(14.25 \times 11 \mathrm{~m})$ on the third floor (Fig. 6 ). The whole structure was surrounded by a wood and earth embankment and the area between the embankment and the palace from the west was paved with cobbles. In the northern part of the court, under the defensive embankment, there was an oval well made of cobbles.

The reliable sources include the remains of one of the palace's rooms, namely a latrine (Fig. 6). It was located in the south-east buttress with an entrance from the room on the second floor and a corridor hidden inside the buttress with a small recess for candles leading to it. The reliable sources also indicate the layout and the size of individual rooms used for residential and utility purposes (5.7$6.7 \mathrm{~m} \times 11.2 \mathrm{~m}$ ) as well as the presence and location of chimney flue inlets, which confirms the presence of heating appliances in individual rooms of the palace. However, their form and size were reconstructed on the basis of iconographic sources. There were hooded fireplaces located in the north-east corner of the room on the second floor and in the south-west corner of the room on the third floor. There was a similar situation in regard to the fireplace located in the middle of the west wall in the representative room. Consequently, all heating appliances should be included in the secondary category data, whose existence was confirmed by sources; however, their form and size were visualized by analogy to this type of appliance known from other buildings with the same chronology.

The hypothetical elements, whose existence is confirmed on the basis of general knowledge of the architecture of a given period, include an external staircase (its layout, size, and form), roofing, and the location of windows in the east facade. It proved impossible to unequivocally establish the original location of the gate in the enclosure embankment wall. It was assumed that the location of the gate, built later in the second half of the 14th century, was connected with the existing layout of the complex and the even older system of roads, especially those of transportation and trade routes. It was established on the basis of this assumption that the gate was located in the east section of the embankment. The whole complex was surrounded by a moat, whose water most probably came from one of the side channels of the Barycz River (Fig. 7). The reconstruction of the kitchen stove in the form of an open, rectangular hearth made of brick and clay is totally hypothetical. A similar level of license was taken regarding the visualization of the kitchen and the basement rooms located on the first floor; at present it is completely filled with debris. 


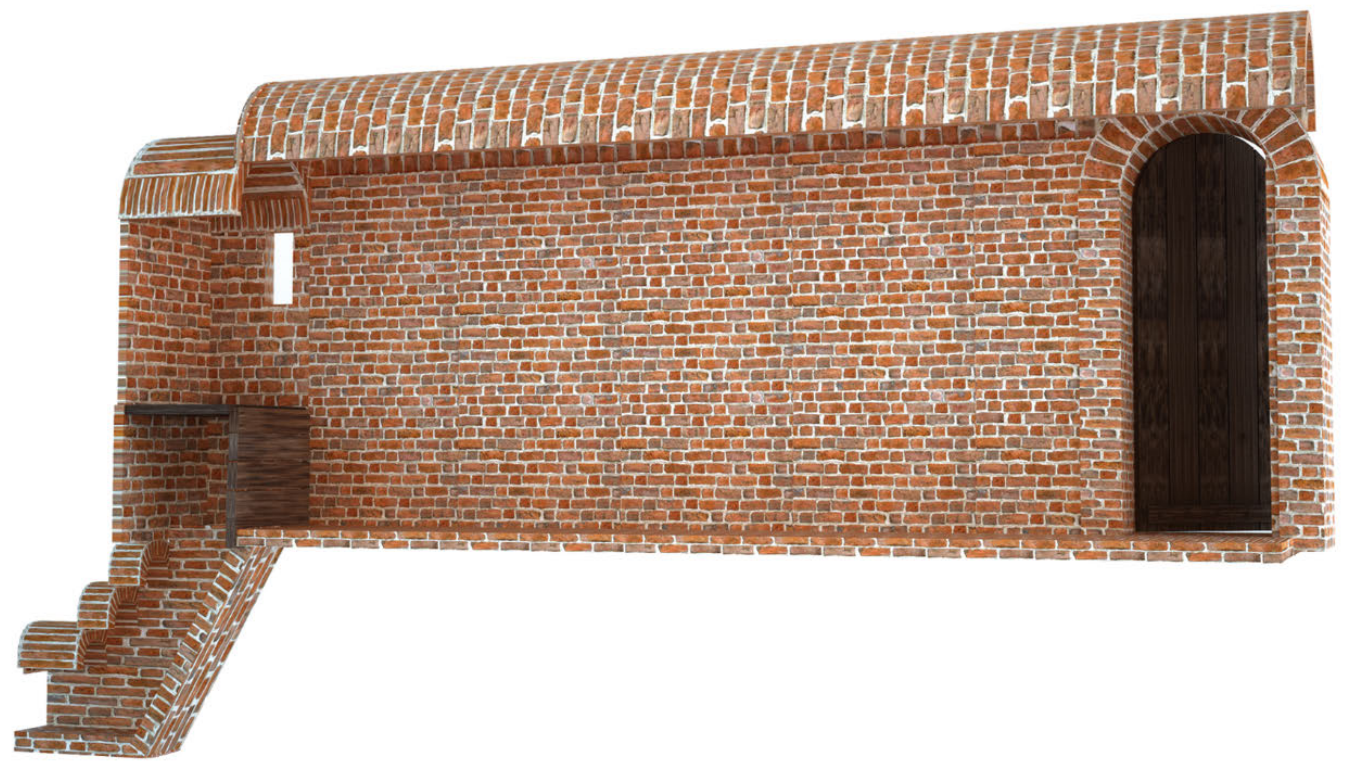

1

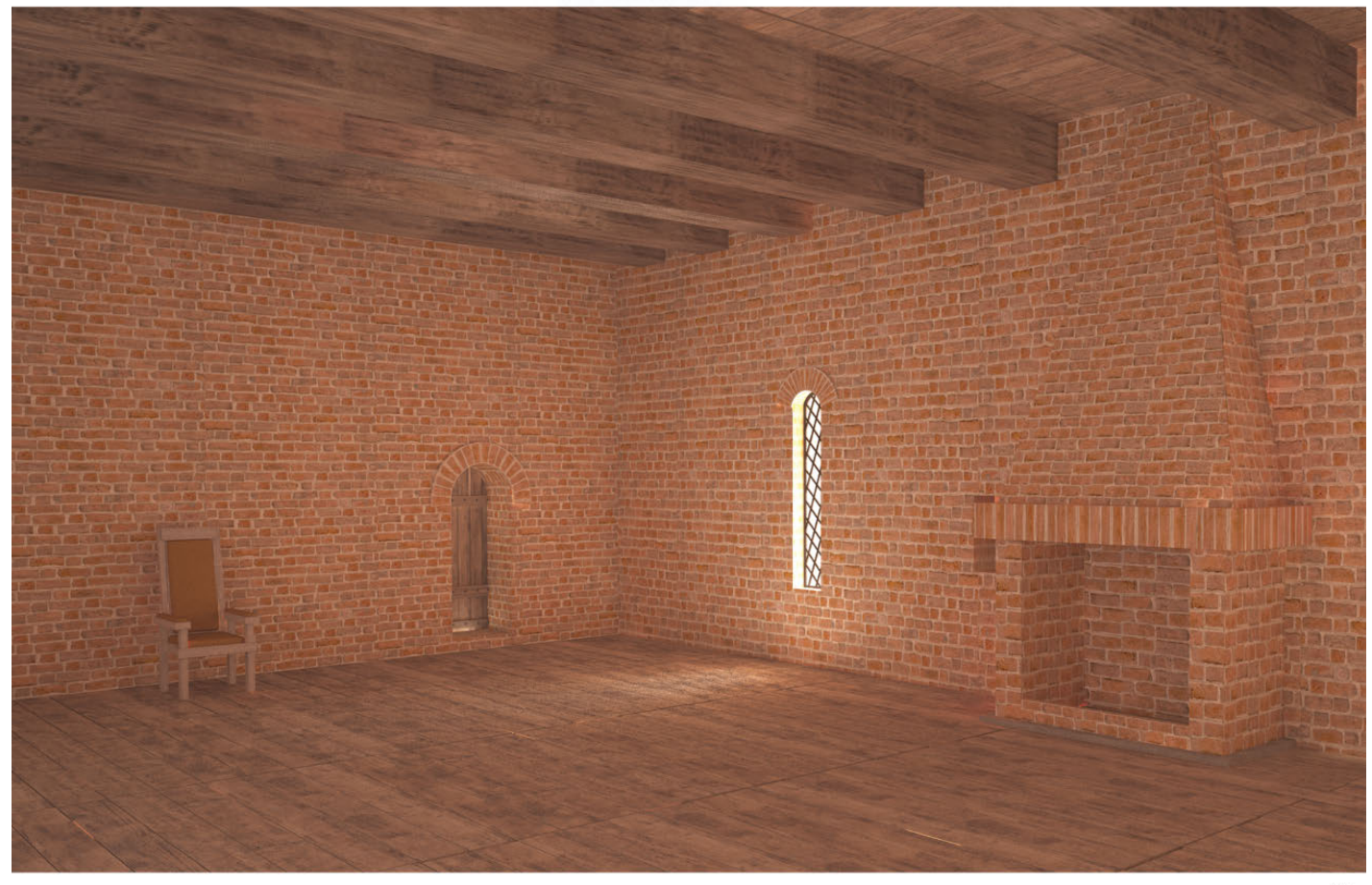

Figure 6. The bishop's palace in Milicz. 3D reconstruction of the latrine and the representative room (by M. Markiewicz). 


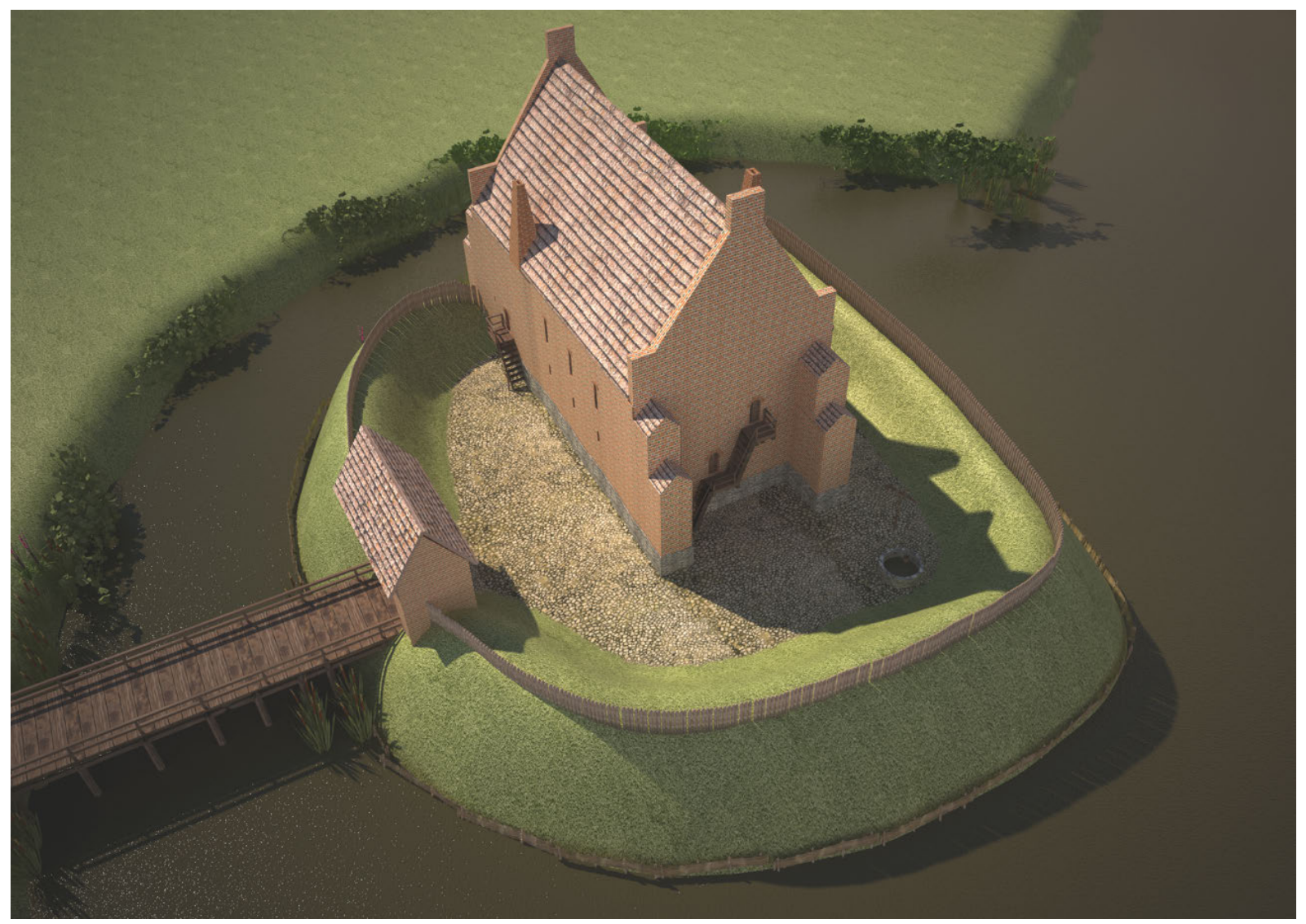

Figure 7. 3D visualization of the bishop's palace in Milicz (by M. Markiewicz).

\section{CONCLUSIONS}

The process of presenting and popularizing the past in modern society is dominated by images. We experience the past through our discernment or perception [Barceló 2014]. The way in which we experience and analyze historical knowledge is determined by how it is presented visually. So far, the information about the bishop's palace in Milicz (the oldest stage of its architecture) has been completely unavailable in the form of 3D visualization and the existing descriptions have not provided a clear picture of its form or function. The presented reconstruction is the first depiction of this type. It is very useful that we can present the findings of research conducted on that structure to the public with the use of a visual message. The choice of the reconstruction in the form of a spatial image resulted from the fact that the software to develop 3D graphics is today an invaluable and increasingly popular tool for visualizing cultural heritage [Barceló 2000; Apollonio 2016]. To see means also to learn, so the digital image is designed for a large group of viewers and it provides added value to the analysis of the past. It also significantly improves the process of remembering new pictorial information and associating it with known information that already exists in the viewer's memory. Another advantage is that the developed model can get critical feedback and it can be 
corrected in accordance with newly gathered data or technical possibilities [Markiewicz 2014]. In Poland this research method has been applied to verify numerous reconstructions proposed for the architectural design in Ostrów Lednicki [Siewczyński 2004]. The analysis of the existing reconstructions of the palace with the use of three-dimensional modeling resulted in the exclusion of spatial solutions which could not have existed for technical reasons.

The digital image of the palace in Milicz, its selected rooms and facilities presents the original form of the historic building, which is at present seriously damaged and as such difficult to see among the ruins. We are aware that the three-dimensional method of modeling which we used is not a breakthrough in the application of this technique in architectural and archeological studies. However, its use is significant because even if that historical object is secured and converted into socalled permanent ruins, it will never assume the form or the layout of the oldest stage. It will only conserve the best-preserved elements from individual stages of the times when the building was used. That is why the visualization of the oldest stage of the building (bishop's palace) is the only way to present it to the academic community and to the public. The church in the town of Bezławki is a good example of this type of popularization of historical heritage. Just like the palace in Milicz, the church was also remodeled a number of times; first it served as a castle of the Teutonic knights, then as a residence of a noble family and finally as a Protestant church. ${ }^{2}$ It is only through a visualization of individual stages that the whole history of the palace can be followed. The presentation of a threedimensional model of the bishop's palace in Milicz to the public will trigger a discussion about this historic site. A lot of questions were asked during the visualization process which could be answered only during the reconstruction of the ruins. It can be claimed on the basis of research experience gained during the reconstruction process that multi-stage buildings which are in ruins and whose process of destruction continues require an individual research approach. The development of a proper research approach depends then on the number of remodeling stages and their extent (e.g. changes to the older walls, demolition of individual parts, change of function of specific rooms, changes in the furnishings) and the possibility of precise dating of those changes.

\section{REFERENCES}

Fabrizio I. Apollonio. 2016. Classification schemes and model validation of 3D digital reconstruction process. Proceedings of the 20th International Conference on Cultural Heritage and New Technologies 2015 (CHNT 20, 2015). Vienna http://www.chnt.at/wpcontent/uploads/eBook_CHNT20_Apollonio_2015.pdf

Juan A. Barceló. 2000. Visualizing what might be: An introduction to Virtual Reality Techniques in Archaeology. In Juan A. Barceló et al. , eds. Virtual Reality in Archaeology. Oxford: Archeopress, 9-36.

Juan A. Barceló. 2014. 3D modelling and shape analysis in archaeology. In Fabio Remondino and Stefano Campana, eds. 3D Recording and Modelling in Archaeology and Cultural Heritage Theory and best practices. BAR International Series 2598, 15-23.

Anna Bentkowska-Kafel. 2008. Historyczna wiarygodność zabytku wirtualnego. Uwagi na marginesie postulatów Karty londyńskiej. In Agnieszka Seidel-Grzesińska and Ksenia Stanicka-

\footnotetext{
${ }^{2}$ http://www.youtube.com/watch?v=yzwzFLWSZX4\&feature=youtu.be [access: 03.05.2017]
} 
Brzezicka, eds. Nowoczesne metody gromadzenia i udostępniania wiedzy o zabytkach. Wrocław, 44-45.

Richard Beacham et al.. 2008. An Introduction to the London Charter.

http://www.londoncharter.org/fileadmin/templates/main/docs/beacham-denardniccolucci_intro.pdf

Małgorzata Chorowska. 2008. Zamek czy pałac? Ruina zamku w Miliczu na tle średniowiecznych siedzib biskupów w Europie. In Justyna Kolenda, ed. Milicz Clavis Regni Poloniae. Gród na pograniczu. Wrocław, 129-140.

Małgorzata Chorowska and Andrzej Kudła. 2005. Architektura i historia średniowiecznego zamku w Miliczu. In Małgorzata Chorowska et al. eds. Nie tylko zamki. Szkice ofiarowane profesorowi Jerzemu Rozpędowskiemu w 75 rocznicę urodzin. Wrocław, 83-96.

Hugh Denard. 2012. A New Introduction to the London Charter. In Anna Bentkowska-Kafel et al., eds. Paradata and Transparency in Virtual Heritage Digital Research in the Arts and Humanities Series. Ashgate, 57-71.

Joseph Gottschalk. 1930. Beiträge zur Rechts-, Siedlungs-, und Wirtschaftsgeschichte des Kreises Militsch bis zum Jahre 1648. Darstellungen und Quellen zur schlesischen Geschichte, hrsg. vom Verein für Geschichte Schlesiens, Bd. 31. Breslau.

Bohdan Guerquin. 1957. Zamki śląskie. Warszawa.

Bohdan Guerquin. 1974. Zamki w Polsce. Warszawa.

Sorin Hermon and Loukas Kalisperis. 2011. Between the Real and the Virtual: 3D visualization in the archaeological research - expectations and prospects. In Virtual Archaeology Review 2(4), 59-63.

David Johnson. 2008. Architectural Drafting Standards in Archaeological Computer Modeling:

Reconstructions from Drawings and Surveys of the Metropolitan Museum of Art Egyptian

Expedition. In CAA 2007: 3D Modelling and Visualisation

http://proceedings.caaconference.org/paper/41_johnson_caa2007/

Andrzej Kudła. 1988. Kontynuacja badań na zamku w Miliczu. Wrocław. The typescript is in the archives of Wojewódzki Urząd Ochrony Zabytków in Wrocław.

Małgorzata Markiewicz. 2014. Archeologia wirtualna - zagrożenie czy przyszłość. Rekonstrukcja 3D w archeologii. In Agnieszka Seidel-Grzesińska and Ksenia Stanicka-Brzezińska, eds. Obraz i metoda. Wrocław, 190-197.

Józef Plich. 1978. Zabytki architektury Dolnego Śląska. Wrocław-Warszawa-Kraków-Gdańsk.

Alexandra Riedel and Thomas Bauer. 2008. Pretty and Useful? - Three-dimensional Computer Models as a Working Tool for Documentation and Investigation in Building Archaeology. In CAA 2007: 3D Modelling and Visualisation.

http://proceedings.caaconference.org/paper/40_riedel_bauer_caa2007/

Jerzy Rozpędowski and Andrzej Kudła. 1987. Badania archeologiczno-architektoniczne zamku w Miliczu. Wrocław. The typescript is in the archives of Wojewódzki Urząd Ochrony Zabytków in Wrocław.

Borys Sierwczyński. 2004. Zabytki architektoniczne Ostrowa Lednickiego w rekonstrukcji komputerowej. Lednica-Poznań.

Thomas Strothotteet al. 1999. Visualizing Knowledge about Virtual Reconstructions of Ancient Architecture, Proceedings of Computer Graphics International'99, The Computer Graphics Society. IEEE Computer Society. Los Alamitos, USA 1999, 36-43. https://tobias.isenberg.cc/pe 
Stella Sylaiou and Petros Patias. 2004. Virtual Reconstructions in archaeology and some issues for consideration. In The Annual Journal for Culture and Technology published by the Foundation of the Hellenic World, 4. http://www.ime.gr/publications/print/imeros/en/04/article01.html

Received March 2017; revised July 2017; accepted August 2017. 